\title{
TROŠKOVI IZGRADNJE KONSTRUKTIVNOG DIJELA ARMIRANOBETONSKE MONTAŽNE HALE U ZAVISNOSTI OD PODUŽNOG RAZMAKA STUBOVA I GLAVNIH NOSAČA
}

\author{
Ismet Gušić ${ }^{1}$ \\ Bilal Hodžić ${ }^{2}$ \\ Amela Šljivić3
}

UDK: $624: 657.47$

DOI:10.14415/konferencijaGFS 2016.103

Rezime: U ovom radu istraživani su troškovi izgradnje konstruktivnog dijela armiranobetonske montažne hale u zavisnosti od podužnog razmaka stubova i glavnih nosača. Urađen je statički proračun, nacrti armature sa specifikacijama za izgradnju konstruktivnog dijela armiranobetonske montažne hale u četiti različita slučaja podužnog razmaka krovnih nosača tip „A“ raspona 22,0 $\mathrm{m}$. Proračunate su hale sa sekundarnim nosačima od „, $T$ “ greda i podužnim razmakom stubova i krovnih nosača $(\lambda$ $=6,0 \mathrm{~m} ; 7,5 \mathrm{~m} ; 10,0 \mathrm{~m}$ i 12,0m). Na osnovu statičkog proračuna i nacrta armature sa specifikacijama urađen je predmjer radova $i$ troškovi izgradnje hala sa podužnim razmakom stubova i krovnih nosača $(\lambda=6,0 \mathrm{~m} ; 7,5 \mathrm{~m} ; 10,0 \mathrm{~m}$ i 12,0m). Dobijene vrijednosti troškova izgradnje hale za svaki razmak stubova su prikazani tabelarno $i$ grafički preko dijagrama. Izvršena je analiza dobijenih rezultata u tabelama $i$ dijagramima i na osnovu dobijenih rezultata urađen je zaključak o najpovoljnijem podužnom razmaku stubova i glavnih nosača $i$ date preporuke za buduće projektante.

Ključne riječi: troškovi izgradnje, montažne konstrukcije, podužni razmak, glavni nosač, dispozicija hale, analiza troškova.

\section{OPIS ISTRAŽIVANJA}

U ovom radu izvršeno je istraživanje troškova izgradnje konstruktivnog dijela armiranobetonske montažne hale u zavisnosti od podužnog razmaka stubova i glavnih krovnih nosača. Analize su urađene za armiranobetonsku montažnu halu dimenzija 22,0 x $60,0 \mathrm{~m}$. Glavni nosači su TIP „A“ raspona $22,0 \mathrm{~m}$ i podužnog razmaka stubova i krovnih nosača: $\lambda=6,0 \mathrm{~m}, 7,5 \mathrm{~m}, 10,0 \mathrm{~m}$ i $12,0 \mathrm{~m}$. Sekundarni nosači su „T" grede preko kojih se nalazi sendvič lim koji predstavlja završni sloj krovne konstrukcije.

\footnotetext{
${ }^{1}$ Dr.sci. Ismet Gušić, dipl.ing.građ., Rudarsko-geološko-građevinski fakultet Univerziteta u Tuzli

${ }^{2}$ Mr.sci. Bilal Hodžić, dipl.ing.građ., Rudarski institut Tuzla

${ }^{3}$ Amela Šljivić, Ma dipl.ing.arh., Ahitektonski fakultet Univerziteta u Sarajevu
} 
Contemporary achievements in civil engineering 22. April 2016. Subotica, SERBIA

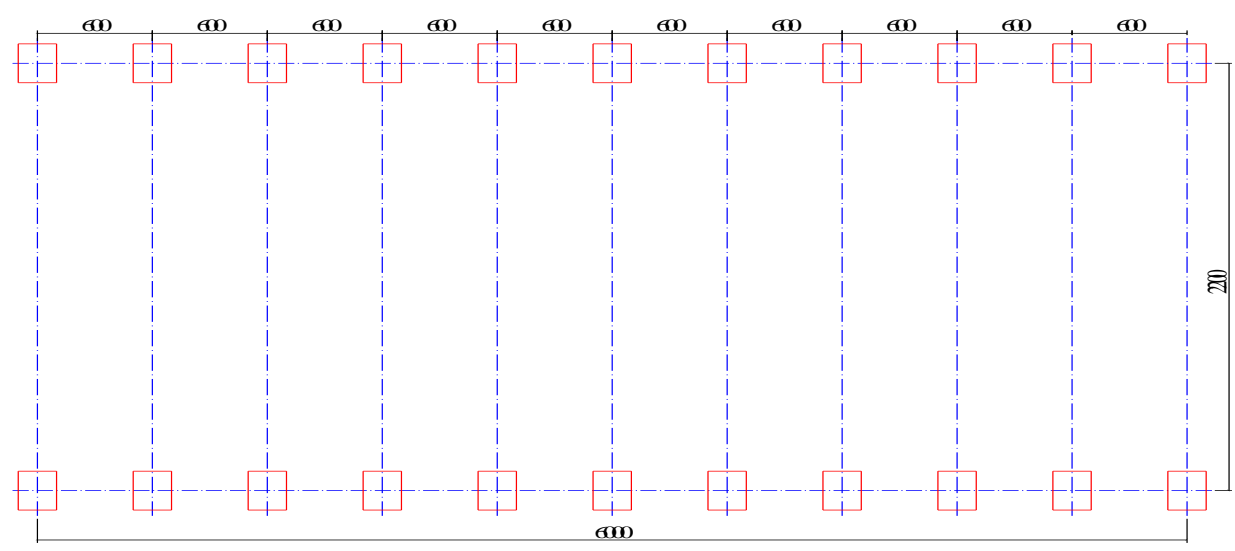

Slika 1. Dispozicija hale sa krovnim „A“ nosačem $l=22,0$ m i podužnog razmaka stubova i glavnih krovnih nosača $\lambda=6,0 \mathrm{~m}$

Urađene su dispozicije za halu $\operatorname{dim} 22,0$ x $60 \mathrm{~m}$, sa slijedećim podužnim razmakom stubova i glavnih nosača:

10 polja sa razmakom stubova u podužnom smijeru $\lambda=6,0 \mathrm{~m}$ 7 polja sa razmakom stubova u podužnom smijeru $\lambda=7,5 \mathrm{~m}$ 6 polja sa razmakom stubova u podužnom smijeru $\lambda=10,0 \mathrm{~m}$ 5 polja sa razmakom stubova u podužnom smijeru $\lambda=12,0 \mathrm{~m}$

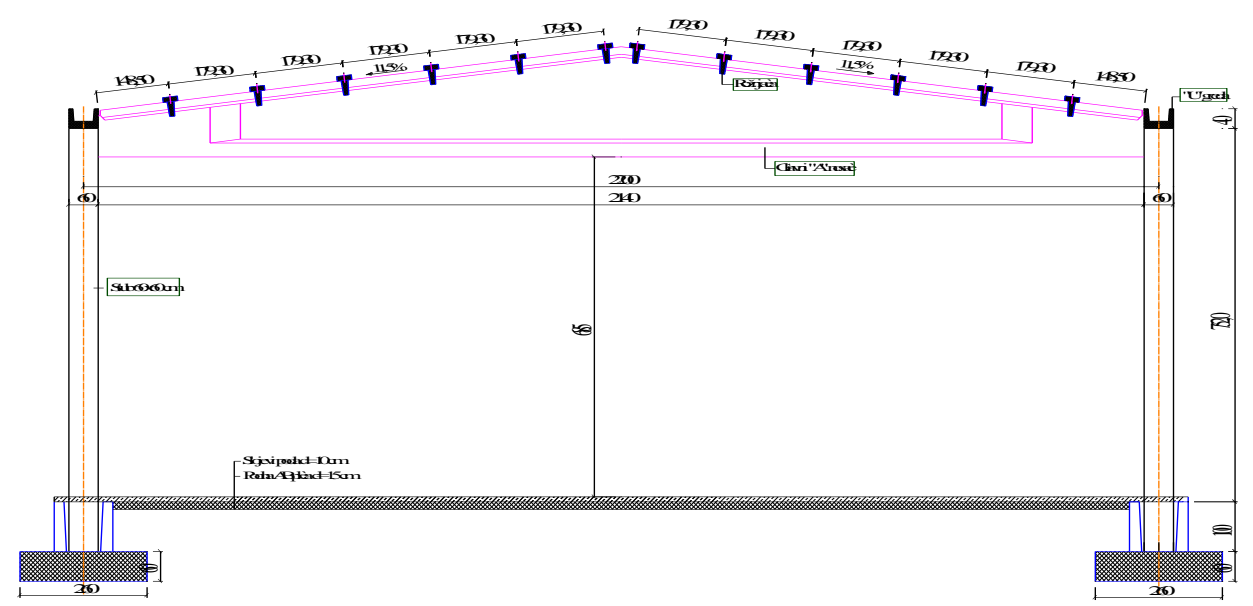

Slika 2. Poprečni presjek hale sa krovnim „,A“ nosačem $l=22,0 \mathrm{~m}$

Za prethodno navedene dispozicije hala urađen je statički proračun, nacrti armature sa specifikacijama armature za izgradnju konstruktivnog dijela armirano-betonske 
montažne hale u četiri različita slučaja podužnog razmaka krovnih nosača TIP „A“ raspona $22,0 \mathrm{~m}$. Izrađeni su proračuni hale sa sekundarnim nosačima od „, $\mathrm{T}^{\text {“ greda } \mathrm{i}}$ podužnim razmakom stubova i krovnih nosača: $\lambda=6,0 \mathrm{~m} ; 7,5 \mathrm{~m} ; 10,0 \mathrm{~m}$ i $12,0 \mathrm{~m}$.

Objekti su projektovani kao jednobrodne prizemne hale. Svijetla visina objekata do rebra krovnog nosača iznosi $6,85 \mathrm{~m}$.

$\mathrm{Za}$ svaku od navedenih dispozicija varijantnih rješenja hale u proračunu je uzeto isto opterećenje koje iznosi: krovni pokrivač $=0,30 \mathrm{kN} / \mathrm{m}^{2}$, vjetar $=0,5 \mathrm{kN} / \mathrm{m}^{2}$, snijeg $=0,75$ $\mathrm{kN} / \mathrm{m}^{2}$, VII seizmička zona, nosivost tla $=300 \mathrm{kN} / \mathrm{m}^{2}$.

Statički proračun i dimenzioniranje za sva varijantna rješenja izvršena su po istom principu uz uzimanje najnepovoljnijih slučajeva opterećenja.

Konstruktivni sistem razmatranog sistema montažnih hala sastoji se od sljedećih elemenata: temeljnih stopa, temeljnih greda, stubova, „U“ korita, krovnih nosača tip „A“ i rožnjača.

\section{Temeljne stope}

Temeljenje konstrukcije izvršeno je na montažnim temeljima samcima. Temeljne stope su izvedene od betona MB 30 i armirane armaturom RA 400/500 kao i mrežama MAR $500 / 560$.

Dimenzije stubova zavise od podužnog razmaka stubova i usvijene su: $\lambda=6,0 \mathrm{~m}$ $210 \times 210 \mathrm{~cm}, \lambda=7,5 \mathrm{~m}, 230 \times 230 \mathrm{~cm}, \lambda=10,0 \mathrm{~m}, 250 \times 250 \mathrm{~cm}, \lambda=12,0 \mathrm{~m}, 260 \times 260$ $\mathrm{cm}$,sa debljinom temeljne stope $\mathrm{d}=60,0 \mathrm{c}$, i visinom čašice $\mathrm{h}=100 \mathrm{~cm}$.

\section{Temeljne grede}

Temeljne grede su dimenzija $25 \times 50 \mathrm{~cm}$ i oslanjaju se na temeljne stope stubova za slučajeve rastera "1" i "2", dok se u slučajevima "3" i "4" oslanjaju i na međutemelje dimenzija 100x100x40 cm. Uvezivanje (monolitizacija) temeljnih greda i temelja vrši se preko ankera koji se ugrađuju u temelj i armature koja je prepuštena iz temeljnih greda. Temeljne grede su izvedene od betona MB 30 i armirane armaturom RA 400/500. Temeljne grede su dimenzionirane na uticaje od konstrukcije, sopstvene težine, kao i za slučaj prilikom montaže.

\section{Stubovi}

U temeljne stope su uklješteni montažni stubovi (hrapava veza) dimenzija 60x60 na koje se oslanjaju i zglobno vezuju poprečne i podužne montažne grede. Stubovi su izvedeni od betona MB 40 i armirani rebrastom armaturom RA 400/500. Stubovi su dimenzionirani na uticaje od krovne kostrukcije, krovnog nosača, U grede, vjetra i seizmičke sile. Proveden je proračun i za slučaj prilikom montaže stubova.

Zglobna veza između glavnog poprečnog "A" nosača "T" presjeka i stubova ostvaruje se bolcnom promjera $\varnothing 22$.

\section{„U“ korito}

Podužne "U" grede (korita) dimenzionirane su na pripadajuće opterećenje sa krova, (opterećenje od krovnog pokrivača, snijega i vjetra), kao i na opterećenja od sopstvene težine.

Veza između podužnog nosača "U" presjeka (korita) i stuba ostvaruje se pomoću dva ankera Ø 14 koji su ispušteni iz kratkih konzola stuba. Pored funkcije ostvarivanja rama 
Contemporary achievements in civil engineering 22. April 2016. Subotica, SERBIA

u podužnom smjeru, "U" nosač (korito) služi i za prijem opterećenja od vjetra, kao i odvođenje vode sa krovne površine.

\section{Krovni nosač TIP „,A“}

Glavni krovni "A" nosač za usvojeni raspon od 22,00 m je nagiba od 11\%. Na gornjoj strani nosača oslanjaju se krovni elementi rožnjače "T" presjeka, koje služe kao nosači krovnog pokrivača (sendvič lim sa termoizolacijom), te opterećenja od vjetra i snijega. Veza između rožnjača i glavnog "A" nosača ostvaruje se pomoću ukosnica koje su prepuštene iz rožnjača i trnova koji se ugrađuju u "A" nosač. Glavni krovni nosač je dimenzioniran na opterećenje od krova, rožnjača, kao i od sopstvene težine. Izvršen je i kontrolni proračun za položaj prilikom transporta i montaže. Krovni nosač je izveden od betona MB 40 i armiran rebrastom armaturom RA 400/500.

Proračun za kompletnu konstrukciju i sve slučajeve rastera vršen je uzimajući najnepovoljnije kombinacije opterećenja kao i faze kao što su: faza vađenja iz kalupa, faza transporta, faza montaže i faza eksploatacije.

\section{Rožnjače}

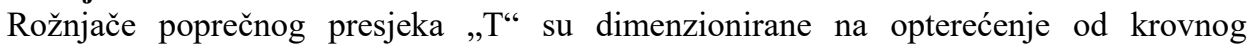
pokrivača, snijega, vjetra i opterećenja od sopstvene težine. Za usvojene konstruktivne sisteme odabran je i razmak rožnjača:

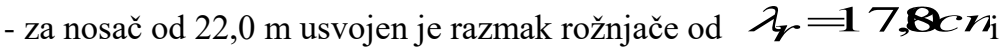

- za slučajeve međusobnog osovinskog razmaka stubova $\lambda=6,0 \mathrm{~m}$ i $\lambda=7,5 \mathrm{~m}$ usvojen je isti poprečni presjek sa debljinom rebra od $d=8,0 \mathrm{~cm}$ i ukupnom visinom $35 \mathrm{~cm}$, dok za slučajeve $\lambda=10,0 \mathrm{~m}$ i $\lambda=12,0 \mathrm{~m}$ usvojen je poprečni presjek sa debljinom rebra $\mathrm{d}=10,0$ $\mathrm{cm}$ i ukupnom visinom $40 \mathrm{~cm}$.

\section{PRORAČUN TROŠKOVA ARMATURE ZA IZGRADNJU KONSTRUKTIVNOG DIJELA HALE U ZAVISNOSTI OD PODUŽNOG RAZMAKA STUBOVA I GLAVNIH NOSAČA}

$\mathrm{Na}$ osnovu statičkog proračuna i nacrta armature sa specifikacijama urađen je predmjer radova i troškovi armature za izgradnju hala sa podužnim razmakom stubova i krovnih

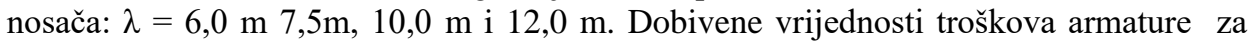
izgradnju hale za navedene razmake stubova su prikazani tabelarno i grafički pomoću dijagrama.

U tabelama (tabela 2) su prikazani troškovi armature za sve konstruktivne elemente za podužni razmak stubova i glavnih nosača $\lambda=7,5 \mathrm{~m}$.

$\mathrm{Na}$ istom principu su urađeni troškovi armature za izgradnju hala sa krovnim nosačem $\mathrm{l}=22,0 \mathrm{~m}$ i rasterom stubova $\lambda=6,0 \mathrm{~m}, \lambda=10,0 \mathrm{~m}$ i $12,0 \mathrm{~m}$ koje su prikazane u tabelama koje nismo stavili u rad zbog ograničenja stranica rada. Prethodno navedene rezultate iz tabela, prikazali smo u tabeli 3 u kojoj su prikazani ukupni troškovi armature za halu sa krovnim nosačem raspona $1=22,0 \mathrm{~m}$ u zavisnosti od razmaka podužnih stubova i glavnih nosača bez obzira da li su tabele prezentirane u radu ili ne.

\section{8} | CONFERENCE PROCEEDINGS INTERNATIONAL CONFERENCE (2016) | 
Савремена достигнућа у грађевинарству 22. април 2016. Суботица, СРБИЈА

Tabela 2. Troškovi armature za izgradnju hale za krovni nosač $l=22,0$ m i raster stubova $\lambda=7,5 \mathrm{~m}$

\begin{tabular}{|c|c|c|c|c|c|}
\hline \multicolumn{6}{|c|}{ Troškovi armature za izgradnju hale za glavni krovni nosač tipa " $A$ " raspona $l=22,0 \mathrm{~m}$} \\
\hline \multicolumn{6}{|c|}{ Raster između stubova $\lambda=7,5 \mathrm{~m}$} \\
\hline $\begin{array}{l}\text { Konstruktivni } \\
\text { element }\end{array}$ & $\begin{array}{l}\text { Količina } \\
\text { armature } \\
(\mathrm{kg} / \mathrm{kom})\end{array}$ & $\begin{array}{c}\text { Broj } \\
\text { elemenata } \\
(\mathrm{kom})\end{array}$ & $\begin{array}{l}\text { Ukupno } \\
\text { armature } \\
(\mathrm{kg})\end{array}$ & $\begin{array}{l}\text { Cijena armature } \\
(\mathrm{KM} / \mathrm{kg})\end{array}$ & $\begin{array}{l}\text { Ukupna cijena } \\
\text { (KM) }\end{array}$ \\
\hline Rožnjača & 91,61 & 112 & $10.260,32$ & 1,50 & $15.390,48$ \\
\hline "U" greda & 117,24 & 16 & $1.875,84$ & 1,50 & $2.813,76$ \\
\hline "A" nosač & $1.228,05$ & 9 & $11.052,45$ & 1,50 & $16.578,68$ \\
\hline Stub & 321,03 & 18 & $5.778,54$ & 1,50 & $8.667,81$ \\
\hline \multirow{3}{*}{$\begin{array}{l}\text { Temeljna } \\
\text { greda }\end{array}$} & 87,42 & 16 & $1.398,72$ & 1,50 & $2.098,08$ \\
\hline & 93,39 & 2 & 186,78 & 1,50 & 280,17 \\
\hline & 49,08 & 4 & 196,32 & 1,50 & 294,48 \\
\hline $\begin{array}{l}\text { Temeljna } \\
\text { stopa }\end{array}$ & 369,09 & 18 & $6.643,62$ & 1,50 & $9.965,43$ \\
\hline Međutemelj & 13,69 & 6 & 82,14 & 1,50 & 123,21 \\
\hline UKUPNO & & & $37.474,73$ & & $56.212,10$ \\
\hline
\end{tabular}

Tabela 3. Ukupni troškovi armature za izgradnjum hale sa glavnim krovnim nosačem tipa " $A$ " raspona l=22,0 m u zavisnosti od podužnog razmaka između stubova i glavnih nosača

\begin{tabular}{|c|c|c|c|c|}
\hline \multicolumn{5}{|c|}{$\begin{array}{c}\text { Ukupni troškovi armature za izgradnju hale sa glavnim krovnim nosačem tipa " } A \text { " raspona l=22,0 mu } \\
\text { zavisnosti od podužnog razmaka između stubova i glavnih nosača }\end{array}$} \\
\hline $\begin{array}{c}\text { Konstruktivni } \\
\text { elementi }\end{array}$ & $\begin{array}{c}\text { Raster } \\
\text { između } \\
\text { stubova } \lambda=6,0 \\
\text { m }\end{array}$ & $\begin{array}{l}\text { Raster između stubova } \\
\qquad=7,5 \mathrm{~m}\end{array}$ & $\begin{array}{c}\text { Raster između } \\
\text { stubova } \lambda=10,0 \mathrm{~m}\end{array}$ & $\begin{array}{c}\text { Raster između } \\
\text { stubova } \lambda=12,0 \mathrm{~m}\end{array}$ \\
\hline Rožnjače & $13.316,10$ & $15.390,48$ & $21.632,94$ & $26.112,38$ \\
\hline "U" grede & $2.546,70$ & $2.813,76$ & $3.488,58$ & $4.416,30$ \\
\hline "A" nosač & $18.322,26$ & $16.578,68$ & $15.605,10$ & $14.212,26$ \\
\hline Stub & $10.593,99$ & $8.667,81$ & $6.741,63$ & $7.023,96$ \\
\hline Temeljna greda & $2.029,14$ & $2.672,73$ & $2.255,61$ & $2.874,24$ \\
\hline Temeljna stopa & $11.838,75$ & $9.965,43$ & $7.985,04$ & $6.928,38$ \\
\hline Međutemelj & 123,21 & 123,21 & 369,63 & 328,56 \\
\hline Ukupno & $58.770,15$ & $56.212,10$ & $\mathbf{5 8 . 0 7 8 , 5 3}$ & $61.896,08$ \\
\hline
\end{tabular}




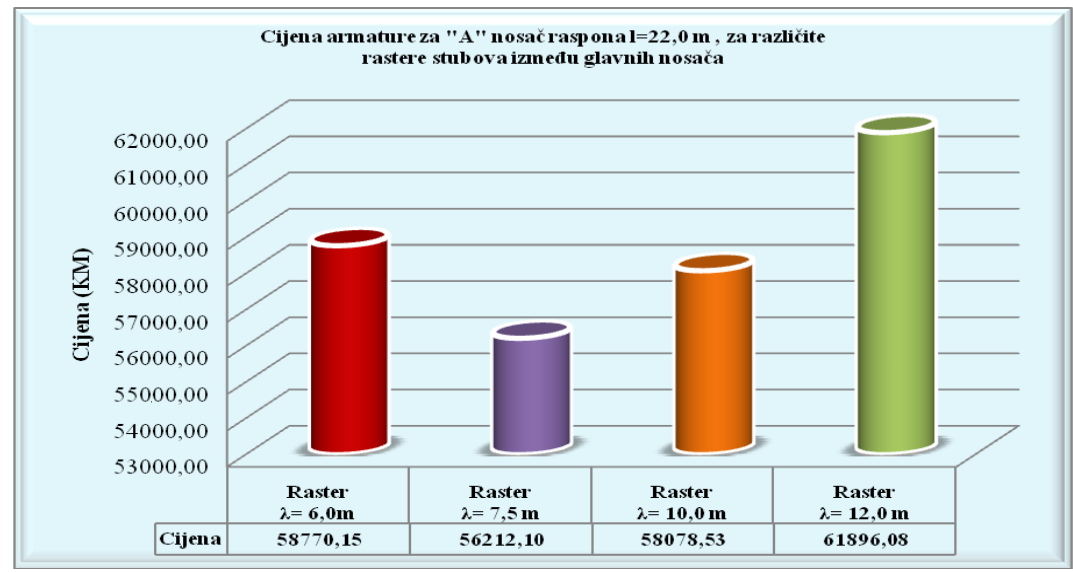

Slika 3. Dijagram ukupnih troškova aramture za izgradnju hale sa glavnim krovnim nosačem tipa " $A$ " raspona l=22,0 $m$ u zavisnosti od podužnog razmaka između stubova i glavnih nosača

\section{PRORAČUN TROŠKOVA BETONA ZA IZGRADNJU KONSTRUKTIVNOG DIJELA HALE U ZAVISNOSTI OD PODUŽNOG RAZMAKA STUBOVA I GLAVNIH NOSAČA}

$\mathrm{Na}$ osnovu statičkog proračuna i plana pozicija urađena je količina potrebnog betona za izgradnju konstruktivnog dijela hale u zavisnosti od podužnog razmaka stubova i glavnih nosača. Urađena je cijena $1 \mathrm{~m}^{3}$ betona sa uračunatom cijenom materijala, izlivanja, odlaganja na deponiju, unutrašnjeg transporta i utovara $u$ proizvodnom pogonu. Množenjem količine betona sa cijenom $1 \mathrm{~m}^{3}$ betona dobijaju se troškovi betonskih radova za izgradnju konstruktivnog dijela hale razvrstani po podužnim razmacima stubova i glavnih nosača. U tabelama koje slijede su prikazani ukupni troškovi betona za izgradnju konstruktivnog dijela hale u zavisnosti od podužnog razmaka stubova i glavnih nosača.

Tabela 4. Troškovi betonskih radova za izgradnju konstruktivnog dijela hale sa glavnim krovnim nosačem tipa "A" raspona $l=22,0 \mathrm{~m}$ i podužnim razmacima stubova i glavnih nosača $\lambda=7,5 \mathrm{~m}$

\begin{tabular}{|c|c|c|c|c|c|}
\hline \multicolumn{6}{|c|}{$\begin{array}{l}\text { Troškovi betonskih radova za izgradnju konstruktivnog dijela hale sa glavnim krovnim nosačem tipa } \\
\text { "A" raspona l=22,0 mi podužnim razmacima stubova i glavnih nosača } \lambda=7,50 \mathrm{~m}\end{array}$} \\
\hline $\begin{array}{l}\text { Konstruktivni } \\
\text { element }\end{array}$ & $\begin{array}{l}\text { Količina } \\
\text { betona } \\
\left(\mathrm{m}^{3} / \mathrm{kom}\right)\end{array}$ & $\begin{array}{l}\text { Broj elemenata } \\
\quad(\text { kom })\end{array}$ & $\begin{array}{l}\text { Ukupno betona } \\
\qquad\left(\mathrm{m}^{3}\right)\end{array}$ & $\begin{array}{c}\text { Cijena betona } \\
\left(\mathrm{KM} / \mathrm{m}^{3}\right)\end{array}$ & $\begin{array}{l}\text { Ukupna cijena } \\
\text { (KM) }\end{array}$ \\
\hline Rožnjača & 0,360 & 112 & 40,32 & 450,00 & $18.144,00$ \\
\hline "U" greda & 0,972 & 16 & 15,55 & 450,00 & $6.998,40$ \\
\hline "A" nosač & 7,930 & 9 & 71,37 & 450,00 & $32.116,50$ \\
\hline Stub & 2,754 & 18 & 49,57 & 450,00 & $22.307,40$ \\
\hline Temeljna greda & 0,713 & 16 & 11,40 & 450,00 & $5.130,00$ \\
\hline
\end{tabular}


Савремена достигнућа у грађевинарству 22. април 2016. Суботица, СРБИЈА

\begin{tabular}{|c|c|c|c|c|c|} 
& 1,025 & 2 & 2,05 & 450,00 & 922,50 \\
& 0,525 & 4 & 2,10 & 450,00 & 945,00 \\
\hline Temeljna stopa & 4,194 & 18 & 75,49 & 400,00 & $30.196,80$ \\
\hline Međutemelj & 0,400 & 6 & 2,40 & 400,00 & 960,00 \\
\hline UKUPNO & & & $\mathbf{2 7 0 , 2 6}$ & & $\mathbf{1 1 . 7 7 2 0 , 6 0}$ \\
\hline
\end{tabular}

Urađeni su troškovi betona za izgradnju konstruktivnog dijela hale sa krovnim nosačem tipa "A" raspona $1=22,0 \mathrm{~m}$ i podužnim razmacima stubova i glavnih nosača $\lambda=6,0 \mathrm{~m}$ i $\lambda=7,5 \mathrm{~m}, \lambda=10,0 \mathrm{~m}$ i $\lambda=12,0 \mathrm{~m}$. Tabele za podužni razmak stubova i glavnih nosača $\lambda=6,0 \mathrm{~m}, \lambda=10,0 \mathrm{~m}$ i $\lambda=12,0 \mathrm{~m}$ su urađene ali nisu prikazane $\mathrm{u}$ radu zbog ograničenja stranica rada. Rezultate iz prethodno navedenih tabela smo uključili u tabelu 5, u kojoj su prikazani ukupni troškovi betona za izgradnju konstruktivnog dijela hale sa glavnim krovnim nosačem tipa "A" raspona $\mathrm{l}=22,0 \mathrm{~m}$ za slučajeve podužnog razmaka stubova i glavnih nosača $(\lambda=6,0 \mathrm{~m}, \lambda=7,5 \mathrm{~m}, \lambda=10,0 \mathrm{~m}$ i $\lambda=12,0 \mathrm{~m})$, bez obzira da li su tabele prezentirane u radu ili ne.

Tabela 5. Ukupni troškovi betona za izgradnjum konstruktivnog dijela hale sa glavnim krovnim nosačem tipa "A" raspona l=22,0 m u zavisnosti od podužnog razmaka između stubova i glavnih nosača

\begin{tabular}{|c|c|c|c|c|}
\hline \multicolumn{5}{|c|}{$\begin{array}{l}\text { Ukupni troškovi betona za izgradnjum konstruktivnog dijela hale sa glavnim krovnim nosačem tipa "A" } \\
\text { raspona l=22,0 m u zavisnosti od podužnog razmaka između stubova i glavnih nosača u KM }\end{array}$} \\
\hline $\begin{array}{l}\text { Konstruktivni } \\
\text { elementi }\end{array}$ & $\begin{array}{c}\text { Razmak između } \\
\text { stubova } \\
\lambda=6,0 \mathrm{~m}\end{array}$ & $\begin{array}{c}\text { Razmak između } \\
\text { stubova } \\
\lambda=7,5 \mathrm{~m}\end{array}$ & $\begin{array}{c}\text { Razmak između } \\
\text { stubova } \\
\lambda=10,0 \mathrm{~m}\end{array}$ & $\begin{array}{c}\text { Razmak između } \\
\text { stubova } \\
\lambda=12,0 \mathrm{~m}\end{array}$ \\
\hline Rožnjača & $17.892,00$ & $18.144,00$ & $23.814,00$ & $25.650,00$ \\
\hline "U" greda & $6.930,00$ & $6.998,40$ & $7.068,60$ & $7.110,00$ \\
\hline "A" nosač & $39.253,50$ & $32.116,50$ & $24.979,50$ & $19.953,00$ \\
\hline Stub & $27.264,60$ & $22.307,40$ & $17.350,20$ & $14.871,60$ \\
\hline Temljna greda & $6.311,25$ & $6.997,50$ & $7.402,50$ & $7.605,00$ \\
\hline Temljna stopa & $31.627,20$ & $30.196,80$ & $26.084,80$ & $17.712,00$ \\
\hline Međutemelj & 960,00 & 960,00 & $2.880,00$ & $2.560,00$ \\
\hline UKUPNO & $130.238,55$ & $117.720,60$ & $109.579,60$ & $95.461,60$ \\
\hline
\end{tabular}

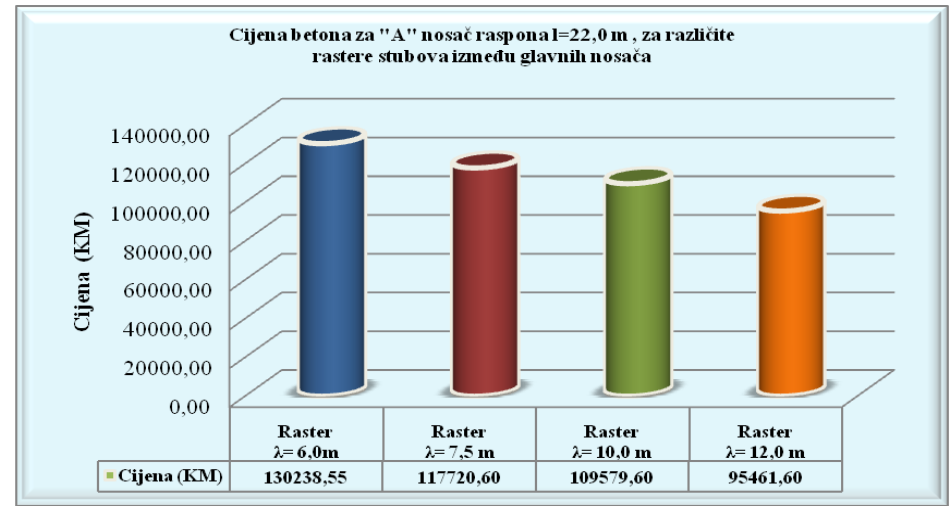

Slika 4. Dijagram ukupnih troškova betona za izgradnju hale sa glavnim krovnim nosačem tipa " $A$ " raspona l=22,0 $\mathrm{m}$ u zavisnosti od podužnog razmaka između stubova i glavnih nosača 
Contemporary achievements in civil engineering 22. April 2016. Subotica, SERBIA

\section{PRORAČUN TROŠKOVA TRANSPORTA, MONTAŽE, RADNE SNAGE I KROVNOG POKRIVAČA U ZAVISNOSTI OD PODUŽNOG RAZMAKA STUBOVA I GLAVNIH NOSAČA}

Urađen je proračun troškova transporta, montaže, radne snage i krovnog pokrivača za sistem hale sa krovnim nosačem raspona $1=22,0 \mathrm{~m}$ i rasterima između stubova $\mathrm{u}$ podužnom smjeru: $\lambda=6,0 \mathrm{~m}, \lambda=7,5 \mathrm{~m}, \lambda=10,0 \mathrm{~m}$ i $\lambda=12,0 \mathrm{~m}$. Troškovi transporta su rađeni na bazi kubature betona pojedinih elemenata koja može da stane u jedno vozilo, troškova jedne ture prevoza sa svim potrebnim zastojima na utovaru i istovaru. Troškovi montaže su rađeni na bazi potrebnog vremena rada dizalice i radne snage za montažu jednog elementa, urađena je potrebna kubatura betona za svaki elemenat i svedeni troškovi na kubni metar pojedinih elemenata. Troškovi krovnih pokrivača za sve dispozicije hale su isti. Na osnovu dobivenih rezultata urađena je tabela 8 , u kojoj je prikazani troškovi transporta, montaže, radne snage i krovnog pokrivača za sistem hale sa krovnim nosačem raspona $1=22,0 \mathrm{~m}$ u zavisnosti od podužnog razmaka između stubova i glavnih nosača.

Tabela 6. Troškovi transporta, montaže, radne snage i krovnog pokrivača za sistem hale sa krovnim nosačem raspona $l=22,0 \mathrm{~m}$ u zavisnosti od podužnog razmaka između stubova i glavnih nosača

\begin{tabular}{|c|c|c|c|c|}
\hline $\begin{array}{l}\text { Raster između } \\
\text { stubova (m) }\end{array}$ & $\begin{array}{c}\text { Troškovi } \\
\mathrm{KM} / \mathrm{m}^{3} \\
\text { betona }\end{array}$ & $\begin{array}{l}\text { Količina } \\
\text { betona }\left(\mathrm{m}^{3}\right)\end{array}$ & $\begin{array}{c}\text { Troškovi krovnog } \\
\text { pokrivača }(\mathrm{KM})\end{array}$ & $\begin{array}{l}\text { Ukupni troškovi } \\
\text { (KM) }\end{array}$ \\
\hline Raster $\lambda=6,0 \mathrm{~m}$ & 341,00 & 298,47 & $67.320,00$ & $169.098,27$ \\
\hline Raster $\lambda=7,5 \mathrm{~m}$ & 315,60 & 270,26 & $67.320,00$ & $152.614,06$ \\
\hline Raster $\lambda=10,0 \mathrm{~m}$ & 276,00 & 251,56 & $67.320,00$ & $136.750,56$ \\
\hline Raster $\lambda=12,0 \mathrm{~m}$ & 267,00 & 217,77 & $67.320,00$ & $125.464,59$ \\
\hline
\end{tabular}

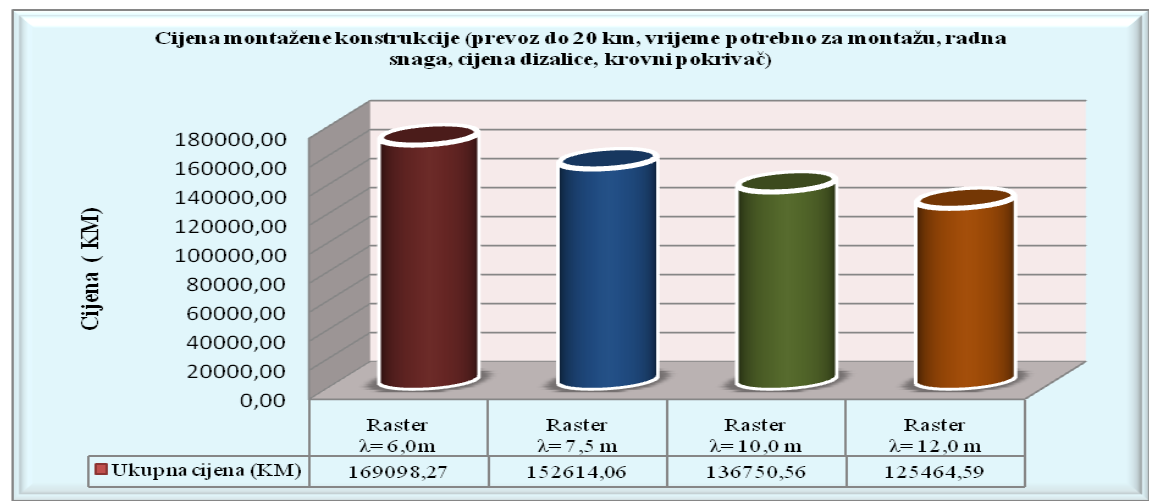

Slika 5. Dijagram ukupnih troškova transporta, montaže, radne snage i krovnog pokrivača za konstrukciju sa rasponom glavnog krovnog nosača $l=22,0 \mathrm{~m}$ u zavisnosti od podužnog razmaka između stubova i glavnih nosača 


\section{ANALIZA DOBIJENIH REZULTATA}

Na osnovu tabele 3 , tabele 5 i tabele 7 , urađena je analiza ukupnih troškova konstrukcije montažne hale sa krovnim „A“ nosačem raspona $1=22,0 \mathrm{~m}$ u zavisnosti od podužnog razmaka između stubova i glavnih nosača.

Tabela 7. Ukupni troškovi izgradnje konstruktivnog dijela armiranobetonske montažne hale sa krovnim „A“ nosačem raspona l=22,0 m u zavisnosti od podužnog razmaka između stubova i glavnih nosača

\begin{tabular}{|c|c|c|c|c|}
\hline \multicolumn{5}{|c|}{$\begin{array}{l}\text { Ukupni troškovi izgradnje konstruktivnog dijela armiranobetonske montažne hale sa krovnim nosačem } \\
\text { tipa "A" raspona l =22,0 m u zavisnosti od podužnog razmaka između stubova i glavnih nosača }\end{array}$} \\
\hline $\begin{array}{l}\text { Razmak } \\
\text { između } \\
\text { stubova }(\mathrm{m})\end{array}$ & $\begin{array}{l}\text { Cijena } \\
\text { armature } \\
(\mathrm{KM})\end{array}$ & $\begin{array}{l}\text { Cijena } \\
\text { betona } \\
(\mathrm{KM})\end{array}$ & $\begin{array}{l}\text { Cijena transporta, montaže, } \\
\text { radne snage, pokrivač } \\
(\mathrm{KM})\end{array}$ & $\begin{array}{c}\text { Ukupna } \\
\text { cijena (KM) }\end{array}$ \\
\hline Raster $\lambda=6,0 \mathrm{~m}$ & $58.770,00$ & $130.238,55$ & $169.098,27$ & $358.106,82$ \\
\hline Raster $\lambda=7,5 \mathrm{~m}$ & $56.212,10$ & $117.720,60$ & $152.614,06$ & $326.546,76$ \\
\hline Raster $\lambda=10,0 \mathrm{~m}$ & $57.078,53$ & $109.579,60$ & $136.750,56$ & $303.408,69$ \\
\hline Raster $\lambda=12,0 \mathrm{~m}$ & $68.196,08$ & $95.461,60$ & $125.464,59$ & $289.122,27$ \\
\hline
\end{tabular}

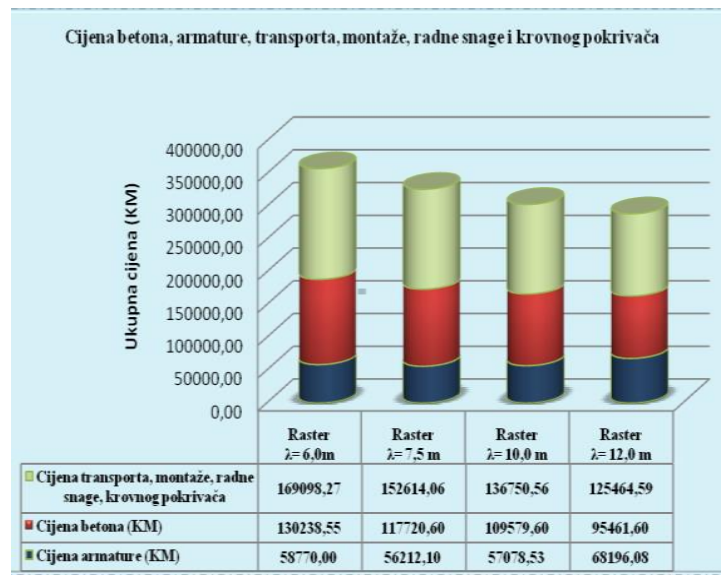

Slika 6. Dijagram ukupnih troškova konstrukcije sa krovnim nosačem raspona $l=22,0$ m u zavisnosti od podužnog razmaka između stubova i glavnih nosača

\section{ZAKLJUČAK}

Urađena je analiza svih prethodno navedenih tabela i dijagrama troškova izgradnje za pojedine podužne razmake stubova i glavnih krovnih nosača na osnovu kojih se došlo do slijedećeg zaključka:

- Najmanji troškovi betona za predmetnu montažnu halu je za podužni razmak stubova i glavnih krovnih nosača $\lambda=12,00 \mathrm{~m}$, a najveći za $\lambda=6,00 \mathrm{~m}$; 
Contemporary achievements in civil engineering 22. April 2016. Subotica, SERBIA

- Najmanji troškovi armature za predmetnu montažnu halu je za podužni razmak stubova i glavnih krovnih nosača $\lambda=7,50 \mathrm{~m}$, a najveći za $\lambda=12,00 \mathrm{~m}$;

- Najmanji troškovi transporta, montaže, radne snage, pokrivača za predmetnu montažnu halu je za podužne razmake stubova i glavnih krovnih nosača $\lambda=$ $12,00 \mathrm{~m}$, a najveći za raster $\lambda=6,00 \mathrm{~m}$;

- Najmanji ukupni troškovi izgradnje predmetne montažne hale je za podužne razmake stubova i glavnih krovnih nosača $\lambda=12,00 \mathrm{~m}$, a najveći za $\lambda=12,00 \mathrm{~m}$;

- Iz istraživanja se zaključilo da je za područje Bosne i Hercegovine od ispitivanih podužnih razmaka stubova i glavnih krovnih nosača najpovoljniji od $\lambda=12,00$ $\mathrm{m}$, a što dovodi do zaključka da se sa povećanjem podužnih razmaka stubova i glavnih krovnih nosača povećava i ekonomičnost izgradnje;

- Ovaj zaključak se odnosi samo u domenu ispitivanih podužnih razmaka stubova i glavnih nosača, jer sa prekomjernim povećanjem razmaka stubova bi se povećali i troškovi;

- Prethodni zaključak ne važi za bilo koju državu, nego se odnosi samo na Bosnu i Hercegovinu za koju je istraživanje i rađeno, jer je odnos cijene materijala, radne snage i mehanizacije promjenljiv u drugim državama, pa bi trebalo za svaku državu uraditi kontrolu ekonomičnosti sa cijenama materijala, radne snage i mehanizacije iz te države;

- Sa ovim radom nisu završena istraživanja već ista mogu poslužiti kao osnova za daljnja istraživanja u ovoj oblasti.

\section{LITERATURA}

[1] Gušić, I.: Organizacija građenja, Papir karton, Tuzla, 2012.

[2] Gušić, I; Šljivić A.: Prefabrikacija i tehnologija montaže, OFF-SET, Tuzla, 2015.

[3] Hasanović, V.: Betonske konstrukcije zbirka riješenih zadataka, Sejtarija d.o.o, Sarajevo, 2005.

[4] Hasanović, V.: Betonske konstrukcije, "Mušinović" d.o.o. Brčko Distrikt, Sarajevo, 2007.

[5] Standardne norme u građevinarstvu.

[6] Trbojević, B.: Organizacija građevinskih radova, Naučna knjiga, Beograd, 1992.

\section{CONSTRUCTION COSTS OF THE STRUCTURAL PART OF REINFORCED-CONCRETE PREFABRICATED FACILITY DEPENDING ON THE LONGITUDINAL DISTANCE BETWEEN THE PILLARS AND MAIN BEAMS}

Summary: The paper analyzes the construction costs of the structural part of a reinforced-concrete prefabricated facility depending on the longitudinal distance 
Савремена достигнућа у грађевинарству 22. април 2016. Суботица, СРБИЈА

between the pillars and the main beams. A statistical calculation was made as well as the reinforcement blueprints with the specifications for the construction of the structural part of the reinforced-concrete prefabricated facility in four different cases of longitudinal distance between the type "A" roof racks with $22.00 \mathrm{~m}$ distance. The calculations were made for the prefabricated facilities with the secondary pillars made of " $T$ " beams and the longitudinal distance between the pillars and the roof racks $(\lambda=$ $6.00 \mathrm{~m} ; 7.50 \mathrm{~m} ; 10.00 \mathrm{~m}$ and $12.00 \mathrm{~m}$ ). Based on the statistical calculation and reinforcement specification, the preliminary draft was made of work and construction costs for the prefabricated facilities with the longitudinal distance between the pillars and the roof racks $(\lambda=6.00 \mathrm{~m} ; 7.50 \mathrm{~m} ; 10.00 \mathrm{~m}$ and $12.00 \mathrm{~m})$. The obtained values of the prefabricated facility construction costs for every distance between the pillars are presented in tables and diagrams. The analysis was made of the obtained results in tables and diagrams. Based on the obtained results, the conclusion was made on the most favorable longitudinal distance between the pillars and the main beams and the recommendations were given for future engineers.

Key words: construction costs, prefabricated facilities, longitudinal distance, main beam, facility slant, cost analysis 